\title{
Determinants of Student Dropouts: A Case Study of Business Students
}

\begin{abstract}
Zafar Zaheer ${ }^{1}$, Shabana Gul' ${ }^{2}$ Imran Wazir ${ }^{3}$, Saima Wazir ${ }^{4}$
Abstract

This study attempts to explore the reasons behind students' dropouts from higher education business schools. For this purpose, data about 1200 students over a period of one year is collected and analyzed from a leading business school in Peshawar. Determinants of dropouts are extracted from the literature and are tested for their association with the dropout decision by the students. Findings of the study are partially aligned with the literature and prove a significant relationship between gender, the type of school attended, students' performance at the SSC and HSSC levels, and major subjects studied at the HSSC level with the incidence of students' dropout from the business school; whereas age, father income, and hometown has shown no relationship with the students' dropout from the business school.
\end{abstract}

Keywords: Dropouts, gender, age, hometown.

\section{Introduction}

One of the greatest assets of a country is its youth; more so an educated youth for they can contribute more to their economy (Pascarella \& Terenzini, 2005). It is empirically proven that those who have a graduate degree can find a job and hold on it more easily as compared to their non-graduate counterparts (Richard \& Parker, 2012). This not only enables them to earn for themselves but also prevent them from becoming a burden on the nation's economy. Thus, one can infer that it is important for a healthy economy to ensure that its youth graduate.

Number of graduates or graduation rate is one of the success indicators of an education system. Though this rate does not indicate that the graduates are equipped with the skills required by the labor market, still it can be used as an indication of the education system's ability to equip students with the minimum requirements of the labor market, i.e. graduation or degree (OCED, 2014). Thus, various strategies are devised and followed by educational institutions in improving this specific index. It

1 Assistant Professor, Institute of Management Sciences, Peshawar. Email: zafar.zaheer@imsciences. edu.pk

2 Assistant Professor, Institute of Management Sciences, Peshawar. Email: shabana.gul@imsciences. edu.pk

3 Associate Professor, Institute of Management Sciences, Peshawar. Email: imran.wazir@imsciences. edu.pk

4 PhD Scholar, Institute of Management Sciences, Peshawar. Email: saima.waxir@gmail.com 
can be achieved by attracting a larger number of students towards higher education, or by retaining those students who are already enrolled in different graduation programs. However, recent studies affirm that higher education institutions are focusing more on attracting new students and their admissions, which result in negligence of the enrolment criteria and procedures (Zemke, 2000). Such compromises on entrance criteria result in higher dropout rates. Therefore, administrators are required to focus more on retaining the already enrolled students as to avoid higher education dropouts (Rumberger, 2001).

It is difficult to define dropouts from educational institutions as researches in the field are still in a state of disarray, mainly because researchers are unable to agree upon the reasons behind student's dropout (Tinto, 1975). In general, dropouts can be defined as those students who either drop out of academic institution on basis of poor academic performance, leave their education in the middle due to financial constraints or do not get graduated for any other social or cultural reason (Pike \& Saupe, 2002).

Education system in Pakistan is divided into five levels i.e. Primary (Grades 1-5), Middle (Grades 6-8), Secondary (Grades 9-10), Higher Secondary (Grades 11-12), and university programs that lead to undergraduate, graduate and advanced degrees (Qadri, 2011). The Government of Pakistan is now more focused on the development of higher education as the number of higher education institutions is increasing with each passing year. It has increased the need for observing higher education of Pakistan more closely. The loopholes need to be identified on time and steps should be taken to remedy them to establish a well performing education system in the country.

Table 6 in annexure shows that the number of higher education institutions is increasing; but no such visible increase is seen in the number of students graduating in succeeding years. It can either be the indication of students dropping out of higher education or that they are taking more than the required time to acquire their degrees. Reasons behind such behavior need to be studied in detail. Initially, a research in the field is required to identify the areas which can be worked upon to improve the situation. Still much is to be done to achieve the goal of a well-established education system in Pakistan.

In Pakistan, the matter of students dropping out of education institutions has been under discussion for some time now. Reasons for dropouts, their outcomes, and other related issues have been studied before but the focal point of such studies remains the primary education of the country (Khan, Tahir, \& Shah, 2011; Begum, Khan, \& Iqbal, 2011; Farooq, 2009; Malik, 2002). 
This study takes the first step by determining the variables that contribute to the increasing number of the students dropping out of higher education. According to Tinto (1975), the attrition behavior of students may differ among institutions. Therefore, a study in which the basic aim is to uncover the factors contributing to dropouts from the higher education institutes, it seems wise to focus on a single institution for empirical analysis for a start-up. Robustness can be achieved later with evidence from other institutions. Furthermore, in the absence of available literature about higher education dropouts in Pakistan, evidence from non-Pakistani literature has been used to classify the variables that are reported to have the most definite effect on a students' dropout. These identified variables are later tested for significance in the case context.

\section{Literature}

In Pakistan, researchers studying dropped out students have mainly focused on the primary level (Farooq, 2009; Khan et al., 2011; Begum et al., 2011; Malik, 2002) with less evidence from higher education. Following table summarizes the major causes

Table 1: Dropout Reasons at Primary Level in Pakistan

\begin{tabular}{|c|c|}
\hline Research Study & Identified Cause \\
\hline \multirow{12}{*}{$\begin{array}{l}\text { Causes of Primary School Students' Dropout in } \\
\text { Punjab Primary School Teachers' Perspective by } \\
\text { Farooq (2016) }\end{array}$} & Most Important Causes: \\
\hline & Class repetition, \\
\hline & Out of school friendships \\
\hline & Difficulties in learning \\
\hline & Family crises and \\
\hline & Child labor \\
\hline & Less Prevailing causes: \\
\hline & Student's psychological problems \\
\hline & Physical characteristics, \\
\hline & Lack of facilities, \\
\hline & Poor relationship with teachers, \\
\hline & Lack of interest in school large class size \\
\hline \multirow{6}{*}{$\begin{array}{l}\text { Gender dimensions of drop out in basic educa- } \\
\text { tion in Pakistan: A Probit analysis by Khan et } \\
\text { al. (2011) }\end{array}$} & Illiterate \\
\hline & mothers \\
\hline & emotionally disturbed children \\
\hline & addiction in family \\
\hline & School at distance \\
\hline & Corporal Punishment \\
\hline
\end{tabular}




\begin{tabular}{|c|c|}
\hline \multirow{7}{*}{$\begin{array}{l}\text { Lack of Primary School Education by Sustain- } \\
\text { able Development Policy Institute } 2011 .\end{array}$} & Poor socio-economic status \\
\hline & Corporal punishment \\
\hline & $\begin{array}{l}\text { Teachers qualification and behavior towards the } \\
\text { child }\end{array}$ \\
\hline & Child labor \\
\hline & School distance \\
\hline & Poor investment by parents \\
\hline & Cultural constraints \\
\hline \multirow{5}{*}{$\begin{array}{l}\text { Socioeconomic Status of the Girl Students and } \\
\text { Their Dropout Rate at Primary Level in F.R. } \\
\text { Kohat (FATA- Pakistan) by Begum et al. } 2011\end{array}$} & Poverty \\
\hline & $\begin{array}{l}\text { Involvement of girls' children in house work/ } \\
\text { farming }\end{array}$ \\
\hline & Religious education of girls \\
\hline & Early marriages of girl's students \\
\hline & Lack of children interest \\
\hline
\end{tabular}

of student dropouts as pinned by the afore-mentioned studies at the primary level.

Though the local (Pakistani) literature's scope is limited to primary education and that too confined to female students, yet there are studies internationally which have focused on dropout phenomena at higher education levels.

There is a wide range of factors at play behind student dropouts. Various studies have pointed these factors via different frameworks. Tinto (1975) was the first to discuss the factors behind the dropouts at length at higher education institutions. Though his model has been subjected to criticism in scholarly circles, yet it helps in understanding the complex nature of students' dropouts. He identified a set of individual and intuitional characteristics for explaining the reasons of such dropouts. Table 2 explains these characteristics and provides a list of other researchers who identified the same factors.

Although Tinto has incorporated different factors of student dropouts, some factors are more important than the others, e.g. individual factors are of more concern as compared to the institutional factors contributing to student attrition (Brunsden, Davies, Shevlin, \& Bracken, 2000). Moreover, Tinto has mainly focused on the students voluntarily giving up their studies in a particular institution. This leaves the discussion of those students who are forced to leave due to unsatisfactory academic performance.

The variables that have been tested to have a significant relationship with students dropping out are, a) Gender, b) Age, c) Score on pre-university examination, 
Table 2: Reasons of Students' Dropouts

\begin{tabular}{|c|c|c|}
\hline Tinto's (1975) Classification & Characteristics & Other Researchers \\
\hline \multirow{15}{*}{ Individual Characteristics } & Family Background: & Astin, 1964 \\
\hline & Socio-economic status & Sewell \& Shah, 1967 \\
\hline & Parents education & \\
\hline & Urban/ rural & \\
\hline & Affluent & \\
\hline & $\begin{array}{l}\text { Quality of relationships within } \\
\text { the family }\end{array}$ & \\
\hline & $\begin{array}{l}\text { Parents expectation and inter- } \\
\text { est in children education }\end{array}$ & \\
\hline & Individual Character: & Astin, 1964 \\
\hline & Ability & Coker, 1968 \\
\hline & Personality & Vaughan, 1968 \\
\hline & Gender & \\
\hline & Past educational experiences & \\
\hline & Goal commitment & \\
\hline & $\begin{array}{c}\text { Interaction within the college } \\
\text { environment }\end{array}$ & \\
\hline & $\begin{array}{c}\text { Academic and social integra- } \\
\text { tion }\end{array}$ & \\
\hline \multirow[t]{5}{*}{ Institutional Characteristics } & 1.Institutional Type: & Astin, 1973 \\
\hline & Public vs Private institutions & \\
\hline & $\begin{array}{l}\text { Two-year college vs Four-year } \\
\text { college }\end{array}$ & \\
\hline & $\begin{array}{c}\text { 2.College Quality \& Student's } \\
\text { Composition }\end{array}$ & \\
\hline & 3.Institution Size & \\
\hline
\end{tabular}

d) Type of pre-university education, e) financial support, and f) Hometown location (Lassibille \& Gomez, 2008; Dekker, Pechenizkiy, \& Vleeshouwers, 2009). These are discussed under.

\subsection{Age}

A number of studies have examined age in relation to performance of students in college. A variety of results have been observed. Some researchers concluded that age does not affect the dropout rate of students. They have found that the number 
of students who drop out is the same across all age groups (see e.g., Bragg, 1956; Suddarth; 1957). Others in their studies have found varying results with a highly significant effect of age on the students' dropouts from educational institutes (Summerskill, 1965; Sexton, 1965). Recent studies also recognize age as a decisive factor in determining the performance of a student in educational institutions (Dekker et al., 2009; Nghe, 2007; Veitch, 2004).

\subsection{Gender}

Literature has a varying record of results regarding the role of gender in students' dropouts. There are those who claim absence of any relationship between the gender of students and their decision to withdraw from further education (Iffert, 1957; Sewell $\&$ Shah, 1967). Yet there are studies that conclude that men persist more in college as compared to women (Astin 1964; Tinto, 1975). Similarly, others battle this stance with completely opposite results i.e. the ration of men dropping out of educational institutes is more as compared to women (Demos, 1968; Nelson 1966). Kuh, Kinzie, Buckley, Bridges, and Hayek (2006) believe that women have been gaining over men in the academic race, thus showing a higher persistence rate in college. Others have also supported the idea of presence of a high significant relationship between the two factors (Dekker et al., 2009).

In Pakistan, gender is considered as a major factor in determining whether a student will graduate or discontinue his/her studies before the completion of his/ her education (Begum et. al, 2011). This can be discerned from the fact that female literacy rate in some areas is as low as 10\%, e.g. in Federally Administered Tribal Areas (FATA) and Baluchistan (Chowdhury, 2005).

\subsection{Father's Income}

It was thought that learning a skill to earn is more profitable as compared to investing in education. However, this concept has been changed and it is reflected in the emphasis on education in the western countries now. But unfortunately, the same behavior is still prevalent in some rural areas in Pakistan. The people there still do not regard education as a necessity. They prefer to start earning as early in life as possible, with whatever skill they have (Begum et al., 2011).

In Pakistan it is a culturally accepted phenomenon that the father's income gives enough indication about a family's socio-economic situation. Socio-economic situation of a family is not only responsible for the monetary support in a child's education, but also the moral support (Coleman, 1988; Kuh et al., 2006). A relationship between father's income and students' dropout from educational institutes does not seem to 
be logically present but is asserted by empirical evidence (see e.g., Suddarth, 1957; Iffert, 1957; Manski, 1992; Choy, 1999; Kuh et al., 2006)

\subsection{Home Town}

Hometown and students' dropouts are significantly related. According to Summerskill (1965), students who belong to a remote area or a smaller town are more likely to drop out. However, Iffert (1957) on the other hand proved the opposite, i.e. students belonging to remote and rural areas are more persistent.

\subsection{Type of High School}

There are varying opinions regarding the impact of the type of high school on the persistence of students in high school. According to some studies, graduates from private high schools are more likely to persist in college as compared to those from public high school (Astin, 1973). However, Sexton (1965) conjectures that this must be so because the students from public schools are driven harder by their motivation to achieve something.

This can be explained with the argument of Dyer (1968) that a student's educational development is affected by the qualitative characteristics of the high school they attend. This can thus be accounted as the reason of why a certain type of school witnesses higher rate of college dropouts as compared to others.

In Pakistan, this factor is expected to have a significant effect on students' behavior because a diverse methodologies are used for the schooling of children. This difference may show its effect in the later stages.

\subsection{Major}

Pre-university selection of courses prepares a student for university life; thus it can be stated that the type of pre-university course that students choose matters in the dropout rate of those students after they enter the university (Lassibille \& Gomez, 2008).

\subsection{Pre-University Academic Performance}

Although there are researchers according to whom, high school GPA does not have a significant effect on the college performance of students (see e.g. Marsh, 1966), yet for others high school GPA has been classified as a major factor that can differentiate between those students who dropout or persist in college. Students who show good performance in school are also expected to persist in college and vice versa. 
Bertrand (1955) calculated this in his study that $73 \%$ of the students who dropped out due to academic reasons were those who were classified in the lowest quartile in high school; whereas $75 \%$ of the students with a probationary status were also from the same quartile. This was asserted by Iffert (1957), according to whom the chance of graduating doubles up for the students classified as top fifth in their class, as compared to the second fifth.

Iffert (1957) points out that although high school performance can be used to predict college performance, yet the same factor cannot be used to judge whether the students will eventually drop out or persist in college. Similar trend is observed by the recent studies, i.e. students have higher probability of succeeding in college who are better prepared from school, regardless of their background or financial setup (Martinez \& Klopott, 2003). High school grades are consistently regarded as strong predictors of first-year college grades, accounting for 25\% to $33 \%$ of the variance (Pike \& Saupe, 2002).

\subsection{Research Hypothesis}

Following hypotheses are developed based on the cited literature:

$\mathrm{H}_{1:}$ There is an association between students' dropout and age

$\mathrm{H}_{2:}$ Male students are more likely to dropout as compared to female students

$\mathrm{H}_{3:}$ There is an association between students' dropout and their hometown

$\mathrm{H}_{4:}$ There is an association between students' dropout and their pre-university academic performance

$\mathrm{H}_{5}$ There is an association between students' dropout and their type of school

$\mathrm{H}_{6:}$ There is an association between students' dropout and their pre-university major subjects

$\mathrm{H}_{7:}$ Students with higher level of father income are more likely to dropout as compared to students with lower level of father income

\section{Methodology}

In this study, data has been collected from the Institute of Management Sciences, Peshawar, Pakistan, with 1200 students graduating in 5 batches making up the sample. It is ensured that they were all tested by the same examination structure, i.e. they all belonged to the similar program, Business Administration. This was done to 
control for such behavior that might arise from the difference in the stress level of students or the courses which students have to cope with. More than one-year data is collected to keep the results as reliable as possible in the given condition following

Table 3: Sample at a Glance

\begin{tabular}{|c|c|c|c|}
\hline Attributes & \multicolumn{3}{|c|}{ Representation } \\
\hline Gender & $83 \%$ Male & \multicolumn{2}{|c|}{$17 \%$ Females } \\
\hline Schooling & $39 \%$ govt. schools & $54 \%$ private schools & $7 \%$ others \\
\hline Majors & $38 \%$ pre medical & $31 \%$ pre-Engineering & $31 \%$ others \\
\hline Drop rate & $\begin{array}{r}13 \% \text { students were dropped out. Majority of these students dropped out } \\
\text { in the first semester, comprised 9\% of the overall sample. }\end{array}$ \\
\hline
\end{tabular}

Pascarella and Terenzini (1980).

After determining the sample, data was collected for the variables narrowed down with the help of literature. University records were used to collect data on academic and demographic background of the students. Students dropping out of the institute were studied in three groups: a) voluntary dropouts, i.e. students who cancelled their admission by their own consent, b) involuntary drop outs, i.e. students unable to perform academically well who had to leave the institute resultantly, and c) students who did not drop out.

Table 4: Operationalizing Variables

\begin{tabular}{|c|c|c|}
\hline Variable & Operational Definition \\
\hline Age & $\begin{array}{c}\text { Age of all the students was scrutinized through statistical techniques before the } \\
\text { application of any analysis. The data was arranged to remove the outliers or the } \\
\text { missing values, and was prepared accordingly for the application of quantitative } \\
\text { techniques. }\end{array}$ \\
\hline Gender & $\begin{array}{r}\text { Students were divided into two classes i.e. Male and Female. Information about } \\
\text { the gender, on each participant, was thus collected on nominal scale. Gender } \\
\text { represents Male = 1, and zero otherwise. }\end{array}$ \\
\hline Home Town & $\begin{array}{r}\text { Towns were categorized into three groups as per the KP development statistics } \\
\text { (2010). } \\
\text { in. Towns with easy access to quality education } \\
\text { iii. Towns with little access to quality education. }\end{array}$ \\
\hline $\begin{array}{c}\text { Pre-university } \\
\text { academic } \\
\text { performance }\end{array}$ & $\begin{array}{c}\text { This variable is quantified with the help of marks obtained by students at SSC and } \\
\text { HSSC levels. SSC marks are the marks obtained by a student in 10th grade whereas } \\
\text { HSSC accounts for the marks obtained in 11th and 12th grade. To standardize the } \\
\text { marks achieved by students at SSC and HSSC levels, all the marks are converted } \\
\text { into percentages. The percentages are then further classified into } 6 \text { groups accord- } \\
\text { ing to the grading system prevalent in Pakistan. }\end{array}$ \\
\hline
\end{tabular}




\begin{tabular}{|c|c|c|}
\hline $\begin{array}{c}\text { Type of } \\
\text { School }\end{array}$ & $\begin{array}{c}\text { Schools are categorized on the basis of the curriculum they follow to educate their } \\
\text { students. The classification is done as: } \\
\text { i. Public Schools, that follow the curriculum and books published by the Govern- } \\
\text { ment } \\
\text { ii. Private Schools, they develop their own curriculum } \\
\text { iii. Schools affiliated with Cambridge: Curriculum in these schools is imported } \\
\text { from Cambridge. }\end{array}$ \\
\hline Major & $\begin{array}{r}\text { Major in this study refers to the courses which students opt for at the HSSC level } \\
\text { of the education system. Following are the different combinations from which } \\
\text { students choose the subjects of their choice: } \\
\text { i. Pre-Medical } \\
\text { ii. Pre-Engineering } \\
\text { iii. Computer Science } \\
\text { iv. Arts Subjects } \\
\text { v. Inter-Sciences } \\
\text { vi. Business Studies }\end{array}$ \\
\hline $\begin{array}{c}\text { Father's } \\
\text { Income }\end{array}$ & $\begin{array}{c}\text { Fathers' income of students has a continuous distribution ranging from Rs.0.3 } \\
\text { million to Rs.1.9 million per year. This variable is standardized with the help of } \\
\text { tax-brackets specified by the Government of Pakistan. With a little adjustment, } \\
\text { seven income classes are established for the students who attend the institute }\end{array}$ \\
\hline
\end{tabular}

\subsection{Definitions of the Variables}

After defining the variables, normality tests were conducted on them and the data was organized for the analysis. The attribute under study, i.e. students dropping out of the higher education, and its association with different factors indicates the use of chi-square test of association.

\section{Analysis \& Results}

Table 5 shows our results for the Chi-square test of association. The test is applied

Table 5: Association of Different Variables with Students' Dropout

\begin{tabular}{|c|c|c|c|c|c|c|c|}
\hline \multirow{2}{*}{ S. No. } & \multirow{2}{*}{ Variable } & \multicolumn{2}{|c|}{ Overall Dropout } & \multicolumn{2}{c|}{ Voluntary Dropout } & \multicolumn{2}{c|}{ Involuntary Dropout } \\
\cline { 3 - 8 } & & $\chi^{2}$-value & p-value & $\chi^{2}$-value & p-value & $\chi^{2}$-value & p-value \\
\hline 1. & Gender & 7.650 & .022 & 91.612 & .000 & $1.107 \mathrm{E} 2$ & .000 \\
\hline 2. & Hometown & 10.278 & .416 & 1.860 & .761 & 3.863 & .569 \\
\hline 3. & Age & 29.931 & .187 & 11.191 & .513 & 19.382 & .080 \\
\hline 4. & Schooling & 11.320 & .023 & 41.306 & .000 & 46.286 & .000 \\
\hline 5. & SSC & 66.846 & .000 & $1.119 \mathrm{E} 2$ & .000 & $1.135 \mathrm{E} 2$ & .000 \\
\hline 6. & HSSC & $1.254 \mathrm{E} 2$ & .000 & 126.296 & .000 & 94.000 & .000 \\
\hline
\end{tabular}




\begin{tabular}{|c|c|c|c|c|c|c|c|}
\hline 7. & Major & 31.441 & .002 & 66.667 & .000 & 12.214 & .016 \\
\hline 8. & Income & 9.958 & .444 & 6.454 & .265 & 2.971 & .705 \\
\hline
\end{tabular}

on each variable for the students who are classified on the basis of three dropout categories: voluntary dropouts, involuntary dropouts, and overall dropouts.

Consistent with earlier studies, current study shows that gender has a significant relationship with students' dropout cases. The coefficient of Gender is significant which means that males tend to drop out more, both voluntarily and involuntarily, as compared to females. The significance with high confidence interval in both segregated cases also indicates that the association is very significant. However, when the overall dropouts were studied together, the confidence interval came from $1 \%$ to $5 \%$, but the results remained the same. In a country with a lower literacy rate for women as compared to men, these results may signify that the male population may take their education and opportunities for granted. It can be noted that as they feel confident about being able to continue their education later in life if needed, they take their initial education lightly

No significant relationship is found between hometown and students' dropout rate. This result is similar for all the three categories of students' dropouts. Our findings show a highly significant association of students' dropouts with the type of school attended by students. The confidence interval to check the association remained at $1 \%$ when tested separately for the segregated groups, i.e. voluntary and involuntary dropouts. Although it went up from $1 \%$ to $5 \%$ when checked for the aggregate outcome, yet the results remained similar, i.e. a significant association between the two variables. The number of students voluntarily dropping out of the institute was significantly higher for those who had been taught at a private school or at one affiliated with the Cambridge.

It can be argued that a student who had been a good performer in the past will show an eagerness to persist in college as well. Our results on the other hand show a different picture. Students who had scored less at the SSC level, have a higher involuntary dropout frequency, whereas those who had scored more than the average have a higher number of voluntarily dropout ratio. This has confirmed our previous belief that those with higher academic score in SSC must find it easier to stay behind. The number of high scorers choosing to drop out and possibly continuing education in some other institute is higher than those who are forced to leave. Whereas below average students, on the other hand, cannot easily cope up with the academic demands and thus are disqualified to continue their studies. It is also of notable importance that as compared to other variables, this shows a consistent high significance with 
both the aggregate dropout rate and the segregated groups.

When tested for the HSSC marks and dropouts, the results resembled those of the SSC marks and their association with the dropout ratio. A highly significant association is observed between these variables, whether it be the aggregate of all the students dropping out or the segregated groups. The pattern, upon further scrutiny, showed resemblance to the results obtained for the SSC marks. Students scoring above average marks leave the institution on their own accord more frequently than those who have scored below average. It may be because that students with greater marks see more career opportunities open for them, thus moving on with a higher confidence in their abilities and dropping out voluntarily from the institution to pursue some other career. This does not stand true for others who have lower marks. They might want to persist in the institute where they are enrolled currently. The number of students leaving the institute willingly is therefore less among those who have a lower percentage of marks scored at the HSSC level. It may either be due to their lower self-confidence or that they find it hard to cope with the challenges of university life.

It was noticed that students from a specialized field at the intermediate level were more likely to dropout voluntarily, whereas others were mostly compelled to leave due to academic reasons. This is also supported by the statistical evidence shown in Table 5. It can also be due to the background from which students come define their aptitude about different subjects which might result in their inability to cope with other subjects that differ from their field of choice.

The presence of association is evident between students' drop out and other factors across all the three sub-groups of the sample. The results show that a greater number of students who voluntarily cancel their admission belong to different specialized groups, i.e. pre-medical, pre-engineering, and computer sciences. To reach at some meaningful results, we re-classified students based on their major subjects into two groups: one containing specialized science category students (pre-medical and pre-engineering), whereas the other group contained all the rest. The results showed a clear difference between students leaving the institute voluntarily and those who are forced to leave, with a very high level of significance.

Concerning father's income, although the literature predicts a positive result, our findings have been different with no relationship spotted between the two variables. The reason for such a finding may be that the sample was collected from a single institutional environment where this factor might not have a significant impact. Robustness check is required in this case by testing the relationship in other institutions as well.

Overall results of the analysis show a significant relationship between the students' 
dropout rate and gender of the student, the type of school which students attend, their performance at SSC and HSSC levels, and the major subjects that they opt for at the HSSC level. The rest of the variables, i.e. age of the students, their hometown, and their father's income indicate no such effect on the dropout rate of students.

\section{Conclusion}

Student's age, father's income, gender, hometown, major subjects opted at HSSC level, performance at SSC and HSSC levels, and type of school attended were extracted from literature as the major causes of student dropouts at higher education institutions. Compared to Table 1, the afore-mentioned variables clearly draw a line between the contextual differences of higher and primary education levels in terms of dropout causes. This point alone demands further exploration in the under-discussion phenomenon at higher education institutions of the country. For instance, the identified variables can be studied to see how their moderation can help to reduce the number of dropouts from higher education institutes.

Furthermore, the case results show partial alignment with literature from other countries and may continue to be so if explored at regional levels within the country. This variation is rooted in the difference of contextual factors that play an important role in students' dropouts at higher education level. Therefore, it is highly suggested that regional studies be conducted to explore and understand the factors behind student dropouts thoroughly. Such studies will pave the way for timely and effective strategic interventions to decrease the dropout ratios at the higher education level.

\section{References}

Astin, A. W. (1964). Personal and environmental factors associated with college dropouts among high aptitude students. Journal of Educational Psychology, 55(4), 219-227.

Astin, A. W. (1973). Student persistence: Some stay, some don't-why? College and University, 48(4), 298-306.

Begum, Z., Khan, I., \& Iqbal, A. (2011). Socioeconomic status of the girl students and their dropout rate at primary level in FR Kohat (FATA-Pakistan). European Journal of Social Sciences, 20(2), 356-384.

Bertrand, J. R. (1955). Relation between high school average grade and academic achievement. College and University, 30, 166-181.

Bragg, E. W. (1956). A study of student withdrawal at "WU”. Journal of Educational Psychology, 47(4), 199-202.

Coker, D. L. (1968). Diversity of intellective and non-intellective characteristics between persisting and non-persisting students among campuses. Unpublished Report. Wisconsin State University, Wisconsin. 
Choy, S. P. (1999). College access and affordability. Education Statistics Quarterly, 1(2), 74-90.

Coleman, J. S. (1988). Social capital in the creation of human capital. American Journal of Sociology, 94, 95-120.

Dekker, G., Pechenizkiy, M., \& Vleeshouwers, J. (2009). Predicting students drop out: A case study. In International Conference on Educational Data Mining, Cordoba, Spain, 41-50.

Demos, G. D. (1968). Analysis of college dropouts-some manifest and covert reasons. Personnel and Guidance Journal, 46(7), 681-684.

Dyer, H. (1968). School factors and equal educational opportunity. Harvard Educational Review, 38(1), $38-56$.

Farooq, M. S. (2009). Development of an inclusive schooling plan for prevention of dropout. Doctoral dissertation, University of the Punjab, Lahore.

Farooq, M. S. (2016). Causes of primary school students' dropout in Punjab: Primary school teachers' perspective. Journal of Elementary Education, 26(1), 57-79.

Lassibille, G., Gómez, L. N. (2008). Why do higher education students drop out? Evidence from Spain. Education Economics, 16(1), 89-105.

Iffert, R. E. (1957). Retention and withdrawal of college students (Bulletin 1958, \# 1). Washington, D. C.: U. S. Government Printing Office.

Khan, G. A., Tahir, M., \& Shah, S. A. (2011). Gender dimensions of drop out in basic education in Pakistan: A Probit analysis. European Journal of Social Sciences, 24(1), 121-133.

Kuh, G. D., Kinzie, J., Buckley, J. A., Bridges, B. K., \& Hayek, J. C. (2006). What matters to student success: A review of the literature. Commissioned report for the national Symposium on postsecondary student success: Spearheading a dialog on student success. Washington DC: National Postsecondary Education Cooperative.

Malik, Z. M. (2002). Causes of dropout in primary schools: A study of primary schools of Sargodha Tehsil during the years 1996-97 \& 1997-98. Pakistan Journal of Applied Sciences, 2(6), 646-648.

Manski, C. (1992). Parental income and college opportunity. Democratic Study Center Report, Washington, DC.

Marsh, L. M. (1966). College dropouts-a review. Personnel and Guidance Journal, 44(5), 475-481.

Martinez, M., \& Klopott, S. (2003). Improving college access for minority, low-income, and first-generation students. Boston: Pathways to College Network.

Nelson, A. G. (1966). College characteristics associated with freshmen attrition. Personnel and Guidance Journal, 44(10), 1046-1050.

Nghe, T. N. (2007). A comparative analysis of techniques for predicting academic performance. Presented at the 
37th ASEE/IEEE Frontiers in Education Conference, Milwaukee.

Pascarella, E. T., \& Terenzini, P. T. (2005). How college affects students: A third decade of research. San Francisco: Jossey-Bass.

Pascarella, E. T., \& Terenzini, P. T. (1980). Predicting freshman persistence and voluntary dropout decisions from a theoretical model. The Journal of Higher Education, 51(1), 60-75.

Pike, G. R., \& Saupe, J. L. (2002). Does high school matter? An analysis of three methods of predicting first-year grades. Research in Higher Education, 43(2), 187-207.

Qadri, H. M. D. (2011, April 30). Analyzing education system in Pakistan. The Frontier Post. Retrieved from http://www.minhaj.org/english/tid/13936/Analyzing-education-system-in-Pakistan.html

Rumberger, R. W. (2001). Why students drop out of school and what can be done. Paper prepared for the Conference, "Dropouts in America: How Severe is the Problem? What Do We Know about Intervention and Prevention? Cambridge, Massachusetts: Harvard University.

Sewell, W., \& Shah, V. (1967). Socioeconomic status, intelligence, and the attainment of higher education. Sociology of Education, 40(1), 1-23.

Sexton, V.S. (1965). Factors contributing to attrition in college populations: Twenty-five years of research. Journal of General Psychology, 72(2), 301-326.

Suddarth, B. M. (1957). Factors influencing the graduation of freshmen who enrol at Purdue University. Unpublished report. Cited in N. Sanford (Ed.), The American college. New York: Wiley, 1962.

Summerskill, J. (1965). Dropouts from college. In N. Sanford (Ed.), The American college. New York: Wiley.

Tinto, V. (1975). Dropouts from higher education: A theoretical synthesis of recent research. Review of Educational Research, 45(1), 89-125.

Veitch, W. R. (2004). Identifying characteristics of high school dropouts: Data mining with a decision tree model. Presented at the Annual Meeting of the American Educational Research Association held in April, San Diego, CA.

Brunsden, V., Davies, M., Shevlin, M., \& Bracken, M. (2000). Why do the students drop out? A test of Tinto's model. Journal of Further and Higher Education, 24(3), 301-310.

Vaughan, R. P. (1968). College dropouts: Dismissed vs. withdrew. Personnel and Guidance Journal, 46(7), 985-689

Zemke, R. (2000). The best customer is the one you have already got. Journal for Quality and Participation, 23(2), 33-35. 


\section{Annexure}

Table 6: Higher Education Statistics

\begin{tabular}{|c|c|c|c|c|c|}
\hline & 2006 & 2007 & 2008 & 2009 & 2010 \\
\hline HE Institutions & 118 & 121 & 126 & 127 & 132 \\
\hline Enrolment & 521473 & 639597 & 738373 & 803507 & 948268 \\
\hline Enrolment males \% & 59.15 & 56.85 & 56.5 & 55.7 & 55 \\
\hline Enrolment females \% & 40.85 & 43.15 & 43.5 & 44.3 & 45 \\
\hline Graduate produced & 380995 & 362684 & 449153 & 496207 & $\mathrm{x}$ \\
\hline
\end{tabular}

Source: The table has been downloaded from the official website of Higher Education Commission of Pakistan. (www.hec.edu.pk) 